\title{
Energy Consumption Model for Open-Space Geometry Building: A Study Case in Jakarta
}

\author{
Arum Kusuma Wardhany, Iwa Garniwa, Rima Kurnia Putri, and Raja Dweyndo Hasintongan Gurning
}

\begin{abstract}
Occupant behaviour and their activity contribute to entire building energy consumption. This study proposes energy consumption prediction model which integrates appliances category, occupancy rates and occupant activity. Site measurement method is used in collecting all appliances along with their operating characteristics. Occupant activity and working behaviour are obtained through questionnaire survey. Simulation results show that energy consumption from base appliances is stable during the working day whereas energy consumption of occupant activity and personal appliances is more fluctuate due to occupancy rates of office building. Validation process with actual energy consumption shows that simulation energy consumption using the proposed model has an average accuracy rate $94 \%$. This model is applicable to predict the energy consumption in open-space office building by knowing occupant behaviour and appliances category.
\end{abstract}

Index Terms-Occupant behaviour, building energy consumption, appliace category, energy consumption model.

\section{INTRODUCTION}

Commercial sector takes $32 \%$ of total energy consumption in 2015 [1]. In office building, electrical energy is usually used for heating, ventilation, and air conditioning (HVAC) equipment, lighting and other electronic office equipment. Some building's variables such as geometry, materials, orientation, ratio, layout, area, height, and energy usage in building are factors that influence total energy consumption [2]-[4]. Estimated energy consumption typically has a gap with the actual value of energy consumption. It is because the energy consumption estimation only focuses on technical aspects such as electronic equipment, building characteristic, and weather.

Occupant behaviour, as non-technical aspect, is often neglected on estimating the energy consumption whereas it is an important aspect. The energy consumption in building mostly occurred by user interaction with electronic equipment [5]. Stazi et al. divided six factors that affect the occupant behaviour likes environment, time-related, contextual, physiological, social, and others [6]. Moreover, user activity, lifestyle, and education level are also contribute to energy consumption [7].

Tetlow et al., investigated other factors that might affect energy consumption in the workplace based on Theory Planned Behaviour which resulted in occupant behaviour has a significant affect to daily energy consumption [8]. On

Manuscript received March 7, 2018; revised June 13, 2018.

The authors are with Electrical Engineering Department, University of Indonesia, Jakarta, Indonesia (e-mail: arum.kusuma61@ui.ac.id, iwa@ee.ui.ac.id, rima.kurnia@ui.ac.id,raja.dweyndo61@ui.ac.id). investigating the occupant behaviour, we can categorize it to two sections: occupancy rates, the number of user in spesific area, and user interaction with the electronic equipment [9], [10]. Occupancy rates is an important parameter to building energy consumption. It can change the annual energy consumption between $69-177 \%$ of the initial value [11] Kim et al. [12] found that occupancy rates and energy consumption of plug load affect the entire building energy consumption. The estimated energy consumption is 5\% lower than the actual value of energy consumption in building by using the model of occupancy rates and electronic equipment[13]. Aside from occupancy rates and interaction to electronic equipment, working hour is another influential factor to energy consumption in office building [14].

In this study, we investigate the effect of appliances category, occupancy rates and occupant activity to building energy consumption. An agent-based approach model is used. The data are collected during working hour in office building in Jakarta, a building with complex behaviour issue.

\section{Research Methodology}

The study is took place in one of office building in Jakarta, Indonesia. The building has a unique characteristic with 53\% open-space geometry area. It is used for working area, digital store, lobby and coffee-shop. The rest area is commonly used for meeting, workshop and IT working room. Due to the unique building geometry, the occupant behaviour on operating electronic equipment in the building is a challenge to investigate.

\section{A. Collecting Data Method}

\section{1) Occupancy, activity and working behaviour}

The studied office building is equipped with the absence machine, records the presence of building's occupant, and Human Resource Management System (HRMS), records the presence of occupant outside the office. The machines help the Human Resource Department to monitor the daily employee presence and working duration from each occupant. Since this study only focuses on the energy consumption in office, occupant presence data from HRMS is neglected. For the purpose of this study, employee were classified into seven working type likes Call Center, IT Infrastructure, Office Boy, Reception, Sales Non-store, Sales Store and Sales Support. A few employee have been choosed to fill out an initial questionnaire about office equipment requirement and their working behaviour, including meeting frequency and usage of appliances in meeting room. List of questions of the questionnaire can be seen in 0 
TABLE I: LIST OF SURVEY QUESTIONS IN THE QUESTIONAIRE

\begin{tabular}{ll}
\hline \hline $\begin{array}{l}\text { Questionnaire } \\
\text { Category }\end{array}$ & Question Item \\
\hline Working Behaviour & Q1 : Arrival Time at office \\
& Q2 : Departing Time from office \\
& Q3 : Meeting frequency per day \\
& Q4: Type of Personal Working \\
Appliances Usage & Qppliances (PC / Notebook) \\
& $\begin{array}{l}\text { Q5 : Type of Appliances which } \\
\text { Appliances }\end{array}$ \\
& Q6 : What to do with electronic \\
& appliances when leaving the office \\
\hline \hline
\end{tabular}

\section{2) Appliances \& operating characteristic}

Energy consumption in office building influenced by various electronic appliancess. Site measurement method and interview with building management were used to find out all electronic equipment in the entire building along with their operational characteristics. Firth et al. [15] classified household electronic appliances based on usage behaviour such as continues, standby, cold, and active appliancess. The electronic appliances in office building have a typical usage behaviour. Zhang et al. [5], classified usage behaviour of electronic appliances based on operation time. Refer to that classification, the appliances on the studied building are categorized to base appliances and flexible appliances due to the building characteristics. The electronic appliances are categorized as base appliances if they have to switch on 24 hours per day, or need to be switched on at specific duration without being affected to number of occupant. Lighting and air conditioner (AC) on working area are also categorized as base appliances because user interaction to switch on/off them is quite low. These appliances are switched on in the morning and switched off at night. The occupant's working appliances and some appliances in meeting or workshop room are categorized as flexible appliances, can be switched on/off in a relatively short time period. The list of electronic appliances used in this study can be seen in Table II

\section{B. Modelling Energy Consumption}

\section{1) Base appliances energy consumption model}

TABLE II: ELECTRONIC APPLIANCES AND OPERATING CHARACTERISTIC IN STUDIED BUILDING

\begin{tabular}{lll}
\hline \hline $\begin{array}{l}\text { Appliances } \\
\text { Category }\end{array}$ & Appliances Name & $\begin{array}{l}\text { Operating } \\
\text { Characteristic }\end{array}$ \\
\hline Base Appliances & $\begin{array}{l}\text { AC at Open Space } \\
\text { Water Dispenser } \\
\text { Freezer \& Refrigerator } \\
\text { Lighting }\end{array}$ & $\begin{array}{l}\text { On during Working Hour } \\
\text { Always ON 24H/7D } \\
\text { Always ON 24H/7D } \\
\text { On during Working Hour }\end{array}$ \\
& Printer & \\
& Screen Display & On during Working Hour \\
& On at 7 a.m \& Off at \\
& Personal Computer & Depend on Employee \\
& Notebook & Depend on Employee \\
& Projector & Depend on Meeting \\
& AC at meeting room & Depend on Meeting \\
& Lighting at meeting & Depend on Meeting \\
& room & \\
\hline \hline
\end{tabular}

As mentioned before, base appliances are the electronic appliances operate without being affected to number of occupant. Energy consumption of base appliances (Ebase), can be formulated as (1).

$$
\begin{aligned}
E_{\text {base }}(\mathrm{t})= & E_{\text {print }}(\mathrm{t})+E_{\text {light }}(\mathrm{t})+E_{A C}(\mathrm{t})+E_{\text {disp }}(\mathrm{t})+ \\
& E_{\text {freeze }}(\mathrm{t})+E_{\text {screen }}(\mathrm{t})
\end{aligned}
$$

where $E_{\text {print }}(\mathrm{t}), E_{\text {light }}(\mathrm{t}), E_{A C}(\mathrm{t}), E_{\text {disp }}(\mathrm{t}), E_{\text {freeze }}(\mathrm{t})$, and $E_{\text {screen }}$ $(\mathrm{t})$, respectively, is energy consumption of printer, lighting, water dispenser, freezer and screen projector during their operating hour $(\mathrm{kWh})$.

\section{2) Occupant appliances energy consumption model}

In studied building, occupant has a various working type, with two categories of personal working appliances such as personal computer (PC) and Notebook. Contrast with base appliances, occupant appliances as a flexible appliances are strongly affected by number of occupant in building. Relation between energy consumption from each type of appliances and number of occupant can be formulated as (2) and (3).

$$
\begin{aligned}
E_{p c}(\mathrm{t}) & =P_{p c} \cdot N_{o c . p c}(\mathrm{t}) \\
E_{\text {note }}(\mathrm{t}) & =P_{\text {note }} \cdot N_{\text {oc.note }}(\mathrm{t})
\end{aligned}
$$

where $P_{p c}$ and $P_{\text {note }}$, respectively, is power consumed by PC and notebook appliances $(\mathrm{kW}), N_{\text {oc.pc }}(\mathrm{t})$ and $N_{\text {oc.note }}(\mathrm{t})$, respectively, is number of occupant using PC and notebook during working hour $(1,2,3, \ldots, n)$.

\section{3) Occupant activity energy consumption model}

Employee activities, meeting, training and workshop, consume more energy besides the energy consumption from their personal appliances. This energy consumption depends on number of activity and duration of each activity, can be defined as (4).

$$
\begin{gathered}
E_{\text {ea }}(\mathrm{t})=\left(E_{\text {meet }}(\mathrm{t}) \cdot N_{\text {meet }}\right)+\left(E_{\text {train }}(\mathrm{t}) \cdot N_{\text {train }}\right)+ \\
\left(E_{\text {work }}(\mathrm{t}) \cdot N_{\text {work }}\right)
\end{gathered}
$$

where $N_{\text {meet }}, N_{\text {train }}, N_{\text {work }}$ represent number of meeting, training and workshop activity during working hour $(1,2$, $3, \ldots, \mathrm{n})$, and $E_{e a}(\mathrm{t})$ indicates total energy consumption from occupant activity during working hour $(\mathrm{kWh})$. By combining (1), (2), (3) and (4), we can derive an equation in (5) to explain the electricity consumption in office building at spesific time.

$$
\begin{aligned}
E_{\text {build }}(\mathrm{t})= & \left\{E_{\text {print }}(\mathrm{t})+E_{\text {light }}(\mathrm{t})+E_{A C}(\mathrm{t})+E_{\text {disp }}(\mathrm{t})+\right. \\
& \left.E_{\text {freeze }}(\mathrm{t})+E_{\text {screen }}(\mathrm{t})\right\}+\left\{E_{p c}(\mathrm{t})+\right. \\
& \left.E_{\text {note }}(\mathrm{t})\right\}+\left\{\left(E_{\text {meet }}(\mathrm{t}) \cdot N_{\text {meet }}\right)+\right. \\
& \left.\left(E_{\text {train }}(\mathrm{t}) \cdot N_{\text {train }}\right)+\left(E_{\text {work }}(\mathrm{t}) \cdot N_{\text {work }}\right)\right\}
\end{aligned}
$$

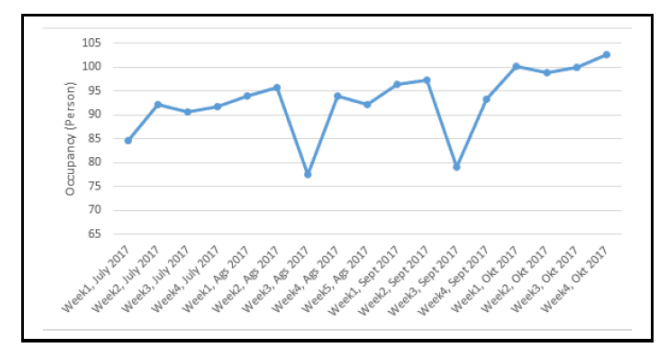

Fig. 1. Weekly Occupancy in the studied building. 
Equation (5) explains how building appliances, occupant appliances and employee activity can contribute to total building energy consumption. This is the improvement for an agent-based model in office building energy consumption.

\section{RESULT AND DISCUSSION}

\section{A. Occupancy Rate \& Employee Behaviour}

The occupancy rates data from absence machine in July to December 2017 was used for estimating daily energy consumption from the occupant appliances and meeting activity. In Fig. 1, we can see that weekly occupancy rates is fluctuating from 80 to 100 employees. The questionnaire result indicates that early coming occupant, arrives at office before 8 a.m, tend to switch on all appliances both personal working appliances and all appliances in the working area, whereas the normal coming employee only switch on their personal working appliances. People who leave the office at 4 p.m to 6 p.m, only switch off their personal appliances and keep the other appliances on Table III and 0show the summary of questionnaire results.

TABLE III: OCCUPANT WORKING BEHAVIOR AND PERSONAL APPLIANCES USAGE

\begin{tabular}{|c|c|}
\hline Parameter & Result \\
\hline \multirow[t]{2}{*}{ Arrival Time at Office } & 6 a.m - 8 a.m : $30 \%$ \\
\hline & 8 a.m - 10 a.m : $70 \%$ \\
\hline \multirow[t]{2}{*}{ Departing Time from Office } & 4 p.m - 6 p.m : $47 \%$ \\
\hline & 6 p.m - 8 p.m : $53 \%$ \\
\hline \multirow[t]{3}{*}{ Meeting Frequency per day } & Never : $53 \%$ \\
\hline & 1-3 Meetings per day : $43 \%$ \\
\hline & 4 - 6 Meetings per day : $6 \%$ \\
\hline \multirow{3}{*}{$\begin{array}{c}\text { Type Of Personal Working } \\
\text { Appliances }\end{array}$} & No appliances : $4 \%$ \\
\hline & Notebook : $76 \%$ \\
\hline & PC : $20 \%$ \\
\hline
\end{tabular}

\section{B. Energy Consumption in the Studied Building}

\section{1) Energy consumption simulation}

TABLE IV: OCCUPANT BEHAVIOUR TO APPLIANCES USAGE

\begin{tabular}{ll}
\hline \multicolumn{1}{c}{ Parameter } & \multicolumn{1}{c}{ Result } \\
\hline $\begin{array}{l}\text { Type of Appliances which switch on } \\
\text { when arrive (Sample can choose } \\
\text { more than 1 appliances) }\end{array}$ & AC : 40\% \\
& Lighting : 37\% \\
& Printer : 37\% \\
& PC : 5\% \\
& Notebook : 43\% \\
& Switch off The appliances : \\
What to do with electronic & $70 \%$ \\
Appliances when leaving the office & Leave it On : 30\% \\
& \\
\hline \hline
\end{tabular}

With $53 \%$ open-space geometry area, interaction between electronic appliances and employee is quite low. Since theoperation of office equipment depends on employee arrival and departure, we can assume that daily operational hour of all office equipment is in line with employee working duration. Average operating time of base appliances such as lighting, AC, and printer is 12 hours per day.

Meanwhile, electrical appliances such as refrigerator, water dispenser and electrical appliances in server room operate 24 hours per day and 7 days a week. The energy consumption simulation of base appliances is 13.13 $\mathrm{MWh} / \mathrm{month}$. This value is not affected by number of occupant per day, but affected by working day per week. The energy consumption simulation of base appliances is 13.13 $\mathrm{MWh} / \mathrm{month}$. This value is not affected by number of occupant per day, but affected by working day per week. In Fig. 2(a) we can see that weekday energy consumption of base appliances is flat, then declined in weekend period. This phenomena occured because in weekend only few appliances in several area is on, whilst the others are off. Energy consumption in weekday tends to be flat although the number of occupant increased or decreased.

Dissimilar from energy consumption of base appliances, Fig. 2 (b) showed the data trend of energy consumption from flexible appliances which is more fluctuating. Average energy consumption simulation of flexible appliances during studied period is $1.65 \mathrm{MWh} / \mathrm{month}$, influenced by number of occupant and meeting frequency of each person in the office. Beside of those two factors, type of personal working appliances is also contribute to the fluctuation of energy consumption. PC needs an electricity supply during the operating time, but for a notebook, it is needed to be recharged after 4 hours.

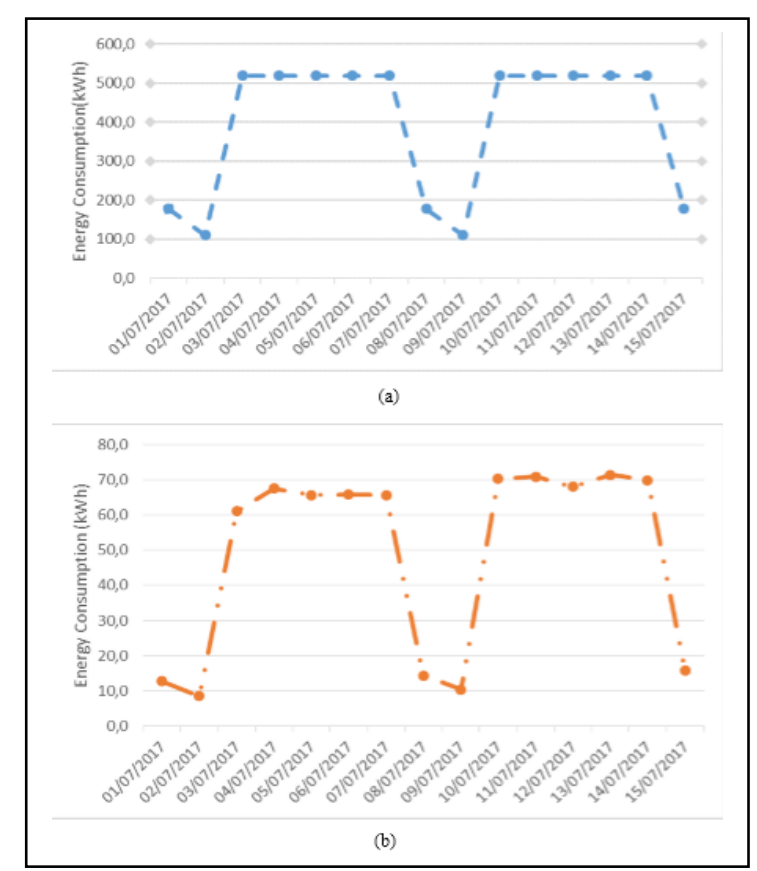

Fig. 2. Sample data trend of energy consumption (a) Base Appliancess (b) Flexible Appliancess

So, the notebook only consumes 2 hours of electricity to recharge the battery. We can conclude that employee who uses PC appliances consumes more energy than employee uses notebook appliances. Because of the strong correlation between number of occupant and their energy consumption, we can assume that the lower number of occupants per day, 
the lower energy is consumed by the appliances. This finding is in line with research conducted by Sandels [16], there are a correlation between occupancy and appliances load to energy consumption.

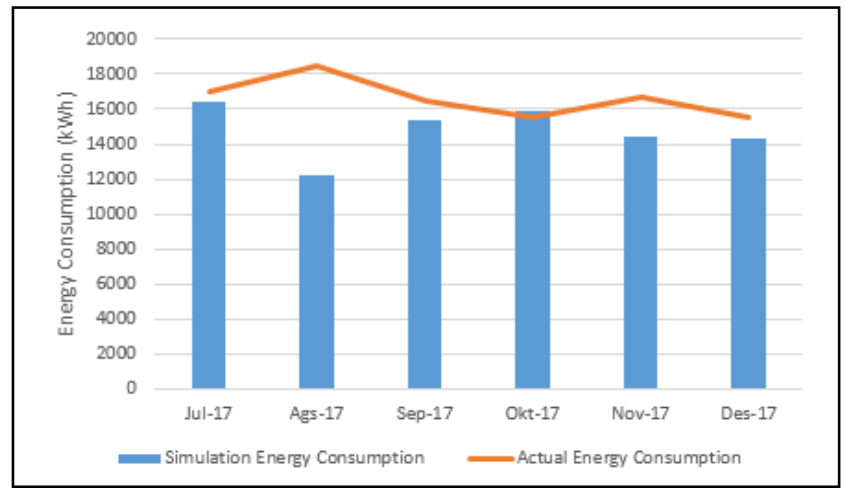

Fig. 3. Comparison between simulation and actual energy consumption.

Employee activity also contribute to increasing building energy consumption. It is because employee needs to switch on the appliances in meeting room during the activity. Energy consumption for an hour meeting in small-medium size meeting room is $0.3 \mathrm{kWh}$, and $2.79 \mathrm{kWh}$ in training and seminar room. Equivalent with personal appliances energy consumption, the energy consumed by meeting activity is rely on meeting frequency per person per day. However, not all employees have a meeting schedule during their working hour. For this type of employee, their energy consumption only come from their personal working appliances

\section{2) Validation data}

To verify the validity of energy consumption of proposed model, monthly energy consumption simulation is compared to actual building energy consumption during studied period. As we seen on Fig. 3, energy consumption simulation using the proposed model is similar to actual energy consumption with accuracy between $86 \%$ - 97\% (average value : 94\%). The unpredictable arising actual energy consumption in August may occured due to seasonal or special activity during the month. It caused significant gap between simulation results and actual energy consumption. Since the proposed model brings the simulation energy consumption similar to the actual consumption, it will help the building management to estimate the energy consumption based on their occupant characteristics, both occupancy and activity rates.

\section{CONCLUSION}

In this study, a new energy consumption model, combining appliances category factors, occupant personal appliances and occupant activity, has been proposed. By categorizing the appliances on their operating characteristics, we can estimate the energy consumption of the entire building. The results showed that base appliances consume 13.13 $\mathrm{MWh} /$ month in average, flat energy consumption during working day and declined on weekend. Meanwhile, average value of flexible appliances energy consumption is $1.65 \mathrm{MWh} /$ month. It has more fluctuating value than base appliances since it depends on number of occupant and meeting activity. The proposed model is applicable for building energy management to anticipate the increasing of energy consumption which previously unpredictable. The simulation of the model can be more accurate compared to actual meeting activity of each person per day and hourly occupancy rates.

\section{REFERENCES}

[1] Handbook of Energy \& Economic Statistics Of Indonesia 2016 - Final Edition, 2016.

[2] Y. Ruan, J. Cao, F. Feng, and Z. Li, "The role of occupant behavior in low carbon oriented residential community planning: A case study in Qingdao," Energy and Buildings, vol. 139, pp. 385-394, 2017.

[3] F. Yousefi, "A study of the impact of occupant behaviors on energy performance ofbuilding envelopes using occupants' data," 2017.

[4] G. Huebner, D. Shipworth, I. Hamilton, Z. Chalabi, and T. Oreszczyn, "Understanding electricity consumption: A comparative contribution of building factors, socio-demographics, appliances, behaviours and attitudes," Applied Energy, vol. 177, pp. 692-702, 2016.

[5] T. Zhang, P. O. Siebers, and U. Aickelin, "Modelling electricity consumption in office buildings: An agent based approach," Energy and Buildings, vol. 43, pp. 2882-2892, 2011.

[6] F. Stazi, F. Naspi, and M. D'Orazio, "A literature review on driving factors and contextual events influencing occupants' behaviours in buildings," Building and Environment, vol. 118, 2017.

[7] B. Pilkington, R. Roach, and J. Perkins, "Relative benefits of technology and occupant behaviour in moving towards a more energy efficient, sustainable housing paradigm," Energy Policy, vol. 39, pp. 4962-4970, 2011.

[8] R. M. Tetlow, C. van Dronkelaar, C. P. Beaman, A. A. Elmualim, and K. Couling, "Identifying behavioural predictors of small power electricity consumption in office buildings," Building and Environment, vol. 92 , pp. $75-85,2015$.

[9] M. Ouf, M. Issa, and P. Merkel, "Analysis of real-time electricity consumption in Canadian school buildings," Energy and Buildings, vol. 128, pp. 530-539, 2016.

[10] C. Wang, D. Yan, and Y. Jiang, "A novel approach for building occupancy simulation," Building Simulation, vol. 4, pp. 149-167, 2011.

[11] C. M. Clevenger, J. R. Haymaker, and M. Jalili, "Demonstrating the impact of the occupant on building performance," Journal of Computing in Civil Engineering, vol. 28, pp. 99-102, 2014.

[12] Y. S. Kim and J. Srebric, "Impact of occupancy rates on the building electricity consumption in commercial buildings," Energy and Buildings, vol. 138, pp. 591-600, 2017.

[13] Z. Wang and Y. Ding, "An occupant-based energy consumption prediction model for office equipment," Energy and Buildings, vol. 109, pp. 12-22, 2015.

[14] T. Hong, D. Yan, S. D'Oca, and C.-f. Chen, "Ten questions concerning occupant behavior in buildings: The big picture," Building and Environment, vol. 114, pp. 518-530, 2017.

[15] K. J. L. S. K. Firth, A. J. Wright, and R. Wall, "Identifying trends in the use of domestic appliances from household electricity consumption measurements," Energy and Buildings, vol. 40, no. 5, pp. 926-936, 2008.

[16] C. Sandels, D. Brodén, J. Widén, L. Nordström, and E. Andersson, "Modeling office building consumer load with a combined physical and behavioral approach: Simulation and validation," Applied Energy, vol. 162, pp. 472-485, 2016.

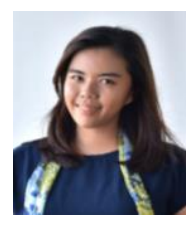

Arum Kusuma Wardhany was born in Solo, 13 Juli 1991. Arum received her Bachelor Degree of Electrical Engineering from Muhammadiyah University of Surakarta, Central Java in 2013 with major field in Power System.

She continue her master degree of electrical and energy management in University of Indonesia, Indonesia. Her research interest in energy consumption and renewable energy research. With previous research, "Building Integrated Photovoltaic for Rooftop and Facade Application in Indonesia" has been publish in international conference, March 2018.

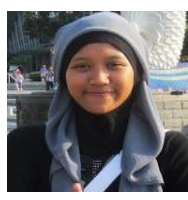

Rima Kurnia Putri was born in Jakarta, 22 November 1993. Rima received her bachelor degree of engineering physics from Institute Technology Bandung, Bandung in 2015. With major field in building physics and accoustic.

She continue her master degree of electrical and energy management in University of Indonesia, Indonesia. Her 
research interest in building physics and renewable energy research. With previous research, "Building Integrated Photovoltaic for Rooftop and Facade Application in Indonesia" has been publish in International Conference, March 2018.

Raja D. H. Gurning was born at Banjarmasin, Indonesia at June, $3^{\text {rd }} 1992$. Received the B. E. degree in electrical power engineering from Institut Teknologi Bandung, Bandung, Indonesia in 2014. He continue her master degree of electrical and energy management in University of Indonesia, Indonesia.

Currently, he is working as engineering service staff at Toyota Motor Manufacturing Indonesia at Jakarta, Indonesia. His research interest in energy application and manufacturing industrial energy optimization and automation.

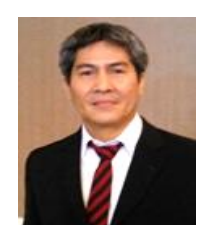

Ir. Iwa Garniwa, M.K., M.T. was born in Bandung, 7 May 1961. Iwa received his bachelor degree of electrical engineering from University of Indonesia in 1987. Prof Iwa joined the department of electrical engineering since 1989.

He earned doctoral degree from Universitas Indonesia in 2000. His research interest includes power quality in distribution systems and high voltage technology. 